\title{
Cost Saving Strategies for Bank Operations
}

\author{
Ann Shawing Yang ${ }^{1}$ \\ ${ }^{1}$ Shu Te University - Dept. of International Business \& Trade \\ 59, Hun Shan Rd., Yen Chao, Kaoshiung County, 82445 Taiwan R.O.C. \\ e-mail: annyang@mail.stu.edu.tw
}

\begin{abstract}
Recent financial liberalization in Taiwan has caused local banks to face major structural changes. This paper examines the cost structure of 36 local banks in Taiwan using the translog cost function and attempts to identify suitable operating strategies for cost reduction and performance improvements. Results indicate scale economies for small and large-sized banks and scope economies for all banks. The establishment of a financial holding company appears to benefit largely those banks affiliated with marketleading insurance conglomerates. These results suggest active diversification should focus on deposits and lending while promoting lending jointly with deposits and investments.
\end{abstract}

Keywords: cost economies, Translog cost function

\section{Introduction}

The study of cost economies in the banking industry is characterized by cost structure analysis for research into scale and scope economies. Both scale and scope economies aim to reduce bank production costs so that efficient firm size and optimal product mix may be met. Because a banking firm is considered a multiple production organization, bank output measures remain an area of question for most studies.

Bank production characteristics are thus a central factor in determining which output measures should be applied. While the multiple output measure and weighted output index have been applied in numerous studies [Powers (1969), Greenbaum (1967), Scheitzer (1972), Benston (1965), Bell and Murphy (1968)] as ways to view bank production in separate non-joint processes and as weighted sums of selected balance sheet items, the single output measure, including total assets or total deposits, is closest to representing the multiple production characteristics of banking firms where cost subadditivity and cost complementarity should be obtained to reduce production costs.

Previous research evidence, when measured by asset sizes, larger banks tend to be more cost efficient than smaller banks. (Murray and White 1983, Hunter and Timme 1986, Mahajan et al., 1996, Flannery, 1983). For largest banks, scale economies may diminish as banks increase in size (Hunter et al. 1990, Gilligan and Smirlock 1984, Gropper 1991, Wang 1996). Other studies, [Gilligan and Smirlock 1984, Gilligan et al. 1984, Berger et al. 1987, Noulas et al. 1990, Gropper (1991)] have found that when one bank surpasses a certain level of assets or does not produce sufficient quantities of certain financial products, scale economies are not easy to obtain. However, Gilligan and Smirlock (1984) found that small banks obtained better scale economy than larger banks when measured by deposit size.

For the search of optimal product mix, studies have also attempted to examine the scope economies between two and three outputs. Studies show optimal product mix involves often deposits, lending and investments. A combination of product investments and lending seems to create diseconomies of scope, and the existence of scope economies is less evident. (Wang 1996, Gilligan et al. 1984, Murray and White 1983, Le Compte and Smith 1990)

This study contributes by identifying key operating activities affecting cost savings of banks. Feasible suggestions and solution strategies are provided to improve bank operations and strategies.

This paper is organized as follows. Section 2 presents the empirical model and methodology. Section 3 presents the results. Section 4 concludes the empirical study.

\section{Model and Methodology}

The Translog Cost Function is adopted to identify the relationships between different inputs and outputs and the total cost of a given banking firm. The intermediation approach is applied to explain the relationships between different bank production factors under a multiple set of inputs and outputs. The linear relationship of the Translog cost function between its inputs and outputs under second-order Taylor series expansion, quadratic in logarithms, and unknown parameters gives it an advantage over other 
types of cost functions in studies of banking scale and scope economies.

Thirty-six Taiwanese banks with complete statistics during the period between 1997 and 2002 were selected as our sample group and sample time. These 36 banks are the leading commercial banks, and include government-held commercial banks, private banks and other financial institutions recently converted to commercial banks. The selected banks have all participated in the financial reform of the Taiwan banking industry and are a good representation of the evolution of the domestic banking market. Sample statistics are taken principally from "Important Activity Statistics of Financial Institutions" published by Central Bank of China (Taiwan), annual reports and requests from individual banks for additional data. The cost function for empirical study is as follows:

$$
\begin{aligned}
\ln T C= & \alpha 0+\alpha 1 \ln Y d+\alpha 2 \ln Y p+\alpha 3 \ln Y t+\beta 1 \ln P l \\
& +\beta 2 \ln P k+\beta 3 \ln P r+1 / 2 \delta 11(\ln Y d)^{2}+1 / 2 \\
& \delta 22(\ln Y p)^{2}+1 / 2 \delta 33(\ln Y t)^{2}+\delta 12 \ln Y d \\
& \ln Y p+\delta 13 \ln Y d \ln Y t+\delta 23 \ln Y p \ln Y t-1 / 2 \\
& \gamma 11(\ln P l)^{2}-1 / 2 \gamma 22(\ln P k)^{2}-1 / 2 \gamma 33 \\
& (\operatorname{lnPr})^{2}+\gamma 12 \ln P \ln P k+\gamma 13 \ln P l \ln P r+ \\
& \gamma 23 \ln P k \ln P r-\rho 11 \ln Y d \ln P l+\rho 12 \ln Y d \\
& \ln P k+\rho 13 \ln Y d \ln P r-\rho 21 \ln Y p \ln P l+\rho 22 \\
& \ln Y p \ln P k+\rho 23 \ln Y p \ln P r-\rho 31 \ln Y t \ln P l+ \\
& \rho 32 \ln Y t \ln P k+\rho 33 \ln Y t \ln P r+\varepsilon 1
\end{aligned}
$$

Formula 1 consists of output deposits $(Y d)$, lending $(Y p)$ and investments $(Y t)$. Inputs are the price of labor $(P l)$, the price of capital $(P k)$ and the price of interest $(P r)$. Certain conditions are necessary to compute our cost function. They are: 1) $\beta 1+\beta 2+\beta 3$ $=1$,2) $\gamma 11+\gamma 21+\gamma 31=0$, 3) $\gamma 12+\gamma 23+\gamma 32=0,4)$ $\gamma 13+\gamma 23+\gamma 33=0,5) \rho 11+\rho 12+\rho 13=0,6) \rho 21+$ $\rho 22+\rho 23=0$, and 7) $\rho 31+\rho 32+\rho 33=0$. Coefficient values are obtained from the multi-variant regression analysis.

The input cost-share equations $(\mathrm{Sj})$ obtained via Shepard's lemma, where $\mathrm{Sj}$ is the share of the jth input in the total variable cost, are:

$$
S j=\beta j+\Sigma i \gamma i j \ln \rho i+\Sigma j \delta i j \ln \alpha j
$$

\section{Empirical Results}

The Translog cost function is estimated jointly with its input cost-share equations using the iterative seemingly unrelated regression (SUR) estimation technique. The iterative Zellner estimation procedure was used to obtain estimates. Based on the $\mathrm{R}^{2}$ at 0.982 and standard error statistics, the fit of the equations is satisfactory. The majority of the parameter estimates are statistically significant at the $5 \%$ level based on a two-tailed t-test. Most of the estimates are statistically significant and carry their expected signs. Table 1 presents the estimated coefficient values.

All bank observations were sorted by asset sizes, yielding a total of five groups: C-1, C-2, C-3, C-4 and $\mathrm{C}-5$, representing banks with assets greater than NT\$100 billion, between NT\$50 billion and NT\$100 billion, between NT\$20 billion and NT\$50 billion, between NT\$10 billion and NT\$20 billion and less than NT\$10 billion, respectively. Within each group, banks are sorted by asset size in descending numerical order. Bank types are sorted by ownership and firm structure. For ownership classifications, public banks are represented by "1" and private banks are represented by “2,". Financial holding companies are represented by " 3 ". Non financial holding companies are represented by " 4 ". For example, $\mathrm{C} 1-1^{1,4}$ represents a public and non financial holding bank with assets exceeding NT\$100 billion.

Scale economy results are under $1 \%$ confidence level with positive estimated values showing constant return to scale for most banking institutions in Taiwan that have long-term average cost curves with a downward sloping trend. Results show banks with assets exceeding NT\$100 billion and with assets between NT\$20 billion and NT\$10 billion possess optimum economies of scale. This empirical result is similar to that obtained by Murray and White (1983) and Hunter and Timme (1986). When compared by asset size, public banks outperform private banks. This empirical result is opposite that of other studies in which private banks are more efficient than public banks in Asia (Karim 2001; Chu et al. 2001).

Results indicate scope economies for banks in all asset sizes. Banks with assets greater than NT\$100 billion and less than NT\$10 billion obtain the best economies of scope. Public banks outperform private banks also in scope economies. These results contradict those of Chu and Chang (1993) and Chu et al. (2001).

A majority of banks in our sample can reduce production costs through product diversification. This cost saving through diversification of product portfolios is larger for the largest and smallest banks. These results contradict the findings of Berger et al. (1987), Rezvanian and Mehdian (2002), and Zardkoohi and Kolari (1994).

The changes in scope economies for the banks over the period under study show a decrease over time, indicating the existence of smaller scope economies in more recent years. This result confirms the finding of Rezvanian and Mehdian (2002).

The establishment of financial holding companies also tends to have limited effects on the levels of scale and scope economy obtained. As observed, the best performing public and private banks 
operate solely as commercial or cooperative banks. For most private banks, the adoption of financial holding company organization structure brings restricted cost reductions. Table 2 presents the scale economy values and scope economy values of Taiwan banks.

\section{Conclusion and Suggestions}

This empirical study uses an econometric analysis based on the transcendental logarithmic cost function to search for deregulation effects on the cost structure of 36 local banks in Taiwan for the period 1997 to 2002. Three banking activities, deposits, lending and investments, were selected as the targets of an analysis of joint production of banking activities in obtaining specific scope economies. This study used an intermediation approach.

The promotion of lending activities seems to be a feasible way to obtain better cost effectiveness when jointly produced with deposits or investments. Technological advancements and branch establishments did not significantly affect the bank cost reduction process. Particular cost increases are evidenced for joint production of deposits and investments. It seems diversification into investment activities may not present the best option for cost reduction. It is also advisable to avoid obtaining tangible goods as capital assets. An alternative would be to employ more staff for daily operations.

The results suggest that the average cost curve for the Taiwanese banking industry is $U$ shaped and that there are economies of scale for small and large banks. The findings further indicate that there are economies of scope for banks of all sizes. This means that joint production of outputs is less costly than producing each output separately. A variety of economies of scope estimates have been made. These broadly indicate that diseconomies of scope exist in the joint production of deposits and investments.

We found that assets above NT\$100 billion was the optimal size for a bank in the local banking industry, from the viewpoint of scale and scope economies. For scope economies, we find banks with assets of less than NT\$10 billion, represented by small and medium business banks (SMEs) that have recently converted to commercial banks. This scope economy may be the result of their superior knowledge in handling a diversity of loans and deposits, since SMEs often require creative financing.

Additionally, public banks appear to be more effective than private banks in reducing production costs in scale and scope economies. Private banks are also able to achieve certain less important levels of scale and scope economies.
The establishment of financial holding companies, however, has very restricted effect on the levels of scale and scope economies obtained. All public banks in our empirical study have maintained their original organizational structure. Private banks that have adopted a financial holding company organizational structure appear to reduce costs through joint production of deposits and lending and of lending and investments. We observed that private financial holding company type banks affiliated with marketleading insurance-based conglomerates are best suited for such activity diversification. They are bank C3-4 and bank C4-10.

\begin{tabular}{|c|c|c|c|}
\hline \multicolumn{4}{|c|}{$\begin{array}{l}\text { TABLE } 1 \\
\text { COEFFICIENT VALUES } \\
\end{array}$} \\
\hline Variables & $\begin{array}{l}\text { Estimated } \\
\text { Coefficient }\end{array}$ & Symbol & $\begin{array}{c}\text { Estimated Coefficient } \\
\text { Values (T value) }\end{array}$ \\
\hline Intercept & Constant & $\alpha 0$ & $19.094(41.333)^{*}$ \\
\hline \multirow{4}{*}{ Outputs } & LnQ1 & $\alpha 1$ & $1.132(1.069)$ \\
\hline & LnQ2 & $\alpha 2$ & $-0.302(-0.642)$ \\
\hline & LnQ3 & $\alpha 3$ & $0.671(1.811)^{*}$ \\
\hline & LnP1 & $\beta 1$ & $0.126(1.828)^{*}$ \\
\hline \multirow{2}{*}{ Inputs } & $\mathrm{LnPk}$ & $\beta 2$ & $0.331(3.760)^{* *}$ \\
\hline & $\mathrm{LnPr}$ & $\beta 3$ & $0.004(0.171)$ \\
\hline \multirow{3}{*}{$\begin{array}{l}\text { Squared } \\
\text { terms of } \\
\text { outputs }\end{array}$} & $(\mathrm{LnQ} 1)^{2}$ & $\delta 11$ & $0.313(1.364)$ \\
\hline & $(\mathrm{LnQ} 2)^{2}$ & $\delta 22$ & $1.432(5.627)^{* *}$ \\
\hline & $(\mathrm{LnQ} 3)^{2}$ & $\delta 33$ & $0.0007(0.211)$ \\
\hline \multirow{3}{*}{$\begin{array}{c}\text { Jointness } \\
\text { of } \\
\text { outputs }\end{array}$} & LnQ1LnQ2 & $\delta 12$ & $-1.767(-4.317)^{* *}$ \\
\hline & LnQ1LnQ3 & $\delta 13$ & $0.944(4.366)^{* *}$ \\
\hline & LnQ2LnQ3 & $\delta 23$ & $-0.984(-4.002) * *$ \\
\hline \multirow{3}{*}{$\begin{array}{l}\text { Squared } \\
\text { terms of } \\
\text { inputs }\end{array}$} & $(\mathrm{LnPl})^{2}$ & $\gamma 11$ & $0.006(7.331)^{* *}$ \\
\hline & $(\mathrm{LnPk})^{2}$ & $\gamma 22$ & $0.005(3.527)^{* *}$ \\
\hline & $(\mathrm{LnPi})^{2}$ & $\gamma 33$ & $0.003(0.697)$ \\
\hline \multirow{5}{*}{$\begin{array}{c}\text { Jointness } \\
\text { of } \\
\text { inputs }\end{array}$} & LnPlLnPk & $\gamma 12$ & $0.004(3.220)^{* *}$ \\
\hline & LnPILnPi & $\gamma 13$ & $-0.009(-4.739) * *$ \\
\hline & LnPkLnPi & $\gamma 23$ & $-0.119(-2.847)^{* *}$ \\
\hline & LnQ1LnP1 & $\rho 11$ & $-0.005(-0.787)$ \\
\hline & LnQ1LnPk & $\rho 12$ & $-0.148(-2.466) * *$ \\
\hline \multirow{7}{*}{$\begin{array}{l}\text { Jointness } \\
\text { between } \\
\text { inputs } \\
\text { and } \\
\text { outputs }\end{array}$} & LnQ1LnPi & $\rho 13$ & $0.303(3.073)^{* *}$ \\
\hline & LnQ2LnP1 & $\rho 21$ & $0.002(0.311)$ \\
\hline & LnQ2LnPk & $\rho 22$ & $0.0003(0.328)$ \\
\hline & LnQ2LnPi & $\rho 23$ & $-0.424(-3.098)^{* *}$ \\
\hline & LnQ3LnP1 & $\rho 31$ & $-0.001(-0.493)$ \\
\hline & LnQ3LnPk & $\rho 32$ & $0.009(1.861)^{*}$ \\
\hline & LnQ3LnPi & $\rho 33$ & $0.005(0.926)$ \\
\hline \multirow{2}{*}{$\begin{array}{l}\text { Controlling } \\
\text { variable }\end{array}$} & Branch & Branch & $0.00007(1.526)$ \\
\hline & Technology & Tech & $-0.001(-1.458)$ \\
\hline
\end{tabular}


TABLE 2

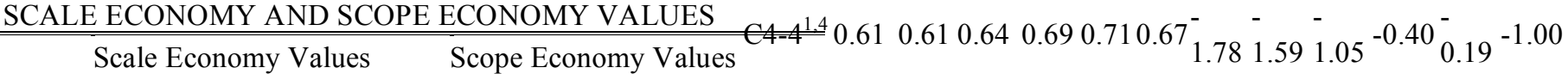

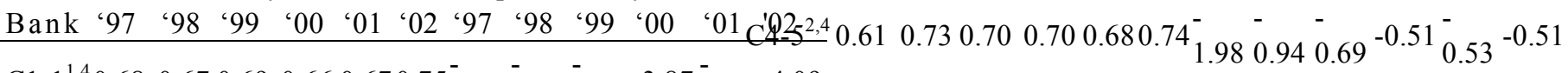

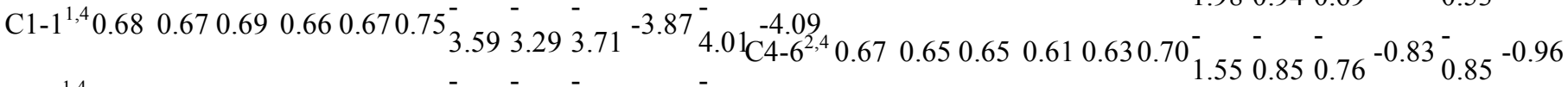

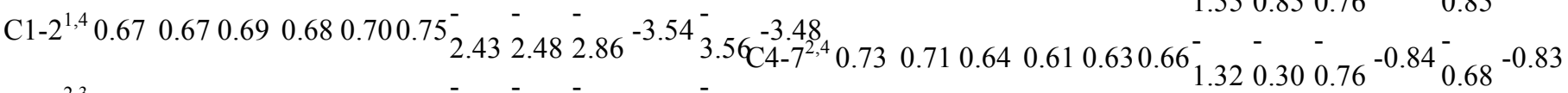

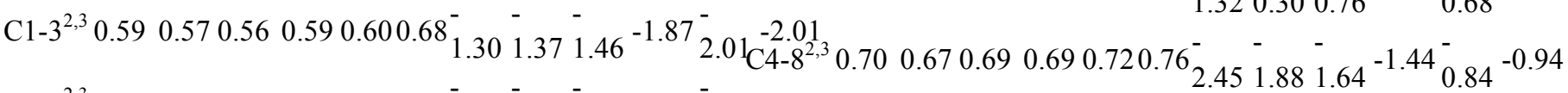

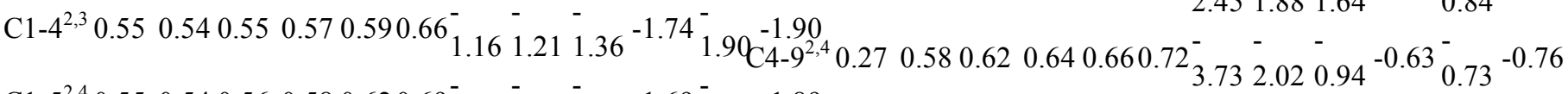

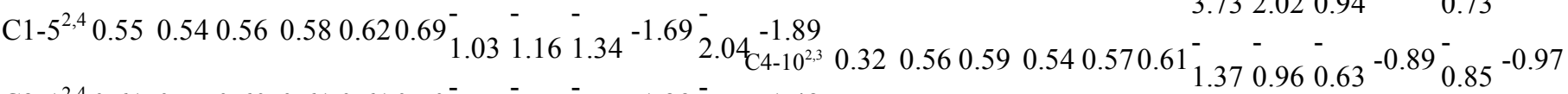

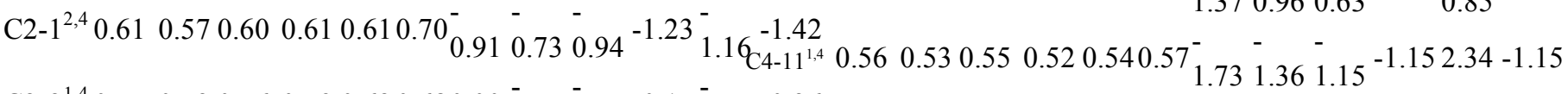

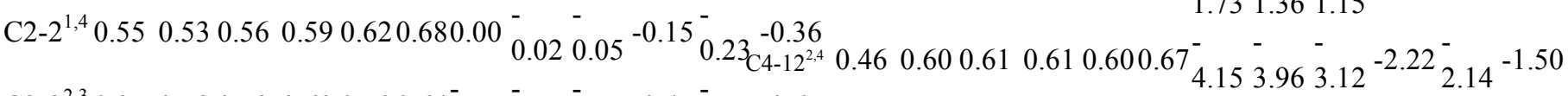

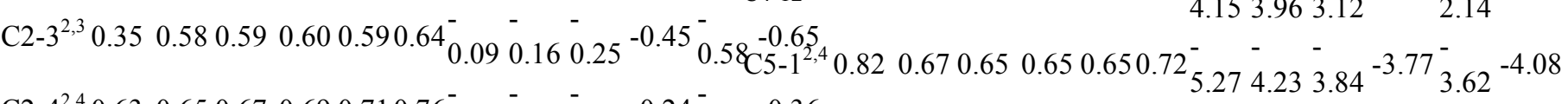

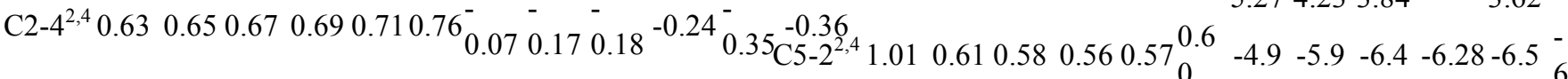
$\mathrm{C} 2-5^{1,4} 0.600 .560 .600 .570 .600 .63^{-} 0.15 \overline{0} 0.19 \overline{0}^{-} .40^{-0.37^{-}} 0.54^{-0.35}$ $\mathrm{C} 2-6^{2,3} 0.340 .350 .380 .500 .460 .53_{0.00}^{-} 0.270 .27-0.05{ }_{0.20}^{-} 0.23$ $\mathrm{C} 2-7^{2,3} 0.690 .660 .620 .640 .620 .67^{-} 0.950 .460 .39^{-0.26} 0.24{ }^{-0.03}$

[1] Berger, A., Hanweck G. and Humphrey D. "Competitive viability in banking: scale, scope and product mix economies." Journal of $\mathrm{C} 2-8^{2,4} 0.510 .480 .560 .570 .570 .650 .010 .06_{0.05^{-}}^{-0.08} 0.088^{-0.08}$ C3-1 ${ }^{2,4} 0.620 .600 .610 .620 .630 .69^{-} 0.270 .280 .26^{-0.18^{-}} 0.19^{-0.23}$ [2] Chu, C.-C. and Chang, T.-G. "Empirical analysis of scale economies and scope economies of Taiwan area banks." Journal of Taiwan Bank, pp. 32-58, 1993.

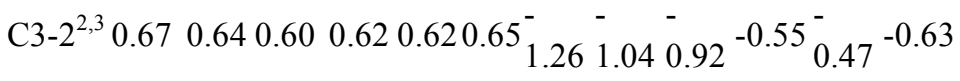
$\mathrm{C} 3-3^{2,3} 0.630 .640 .630 .620 .630 .70_{1.23}^{-} 0.790 .44^{-0.33^{-}} 0.33^{-0.45}$

[3] Chu, K.-K., Ho L.-M. and Tang, J.-F. "Estimate the difference of economical efficiency between the Taiwan new banks and traditional banks." $\mathrm{C} 3-4^{2,3} 0.690 .660 .700 .720 .730 .75_{1.34}^{-} 0.83 \overline{0}^{-} .76^{-0.15^{-}} 0.39^{-0.66}$ C $3-5^{2,4} 0.650 .590 .600 .570 .600 .63_{0.05}^{-} 0.02 \overline{0}_{0.13}^{-}{ }^{-0.16^{-}} 0.35^{-0.39}$

[4] Flannery, M. "Correspondent services and cost economies in commercial Banking." Journal of Banking and Finance, pp. 83-99, 1983.

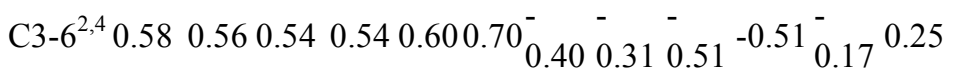
[5] Gilligan, T. and Smirlock, M. "An empirical study of joint production and scale economies in commercial banking." Journal of Banking and

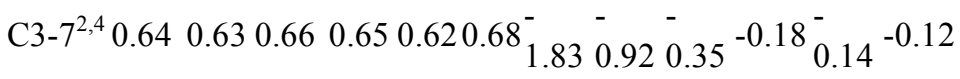
Finance, pp. 67-77, 1984.

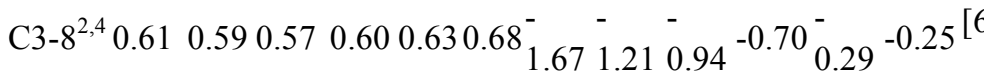

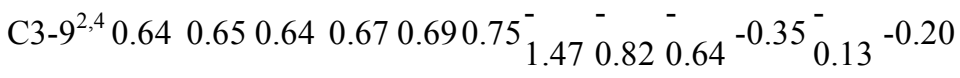

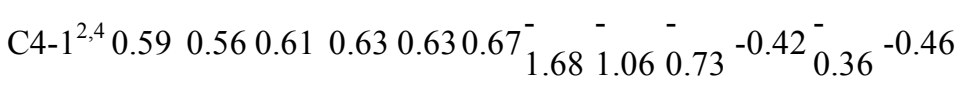
[7] Gropper, D. "An empirical investigation of changes in scale economies for the commercial banking firms 1979-1986." Journal of Money,

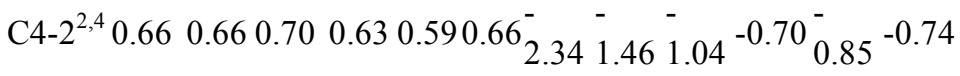
Credit and Banking, pp. 718-727, 1991.

C4-3 ${ }^{2,3} 0.410 .600 .650 .610 .680 .77-\quad$ - $\quad$ - $\quad-1.16$ - $\quad-0.08$ [8] Hunter, W., Timme, S. and Yang W. "An 
examination of cost subadditivity and multiproduct production in large U.S. banks." Journal of Money, Credit and Banking, pp. 504-525, 1990.

[9] Hunter, W. and Timme, S. "Technical change, organizational form, and the structure of bank production." Journal of Money, Credit, and Banking, pp. 152-166, 1986.

[10] Karim, A. "Comparative bank efficiency across select ASEAN Countries." ASEAN Economic Bulletin, pp. 289-304, 2001.

[11] Le Compte, R. and Smith, S. "Changes in the cost of intermediation: the case of savings and loans." The Journal of Finance, pp. 1337-1346, 1990.

[12] Mahajan, A., Rangan, N. and Zardkoohi, A. "Cost structures in multinational and domestic banking." Journal of Banking \& Finance, pp. 283-306, 1996.

[13] Murray, J. and White R. "Economies of scale and economies of scope in multiproduct financial institutions: a study of British Columbia Credit Unions." The Journal of Finance, pp. 887-901, 1983.

[14] Noulas, A, Ray S. and Miller, S. "Returns to scale and input substitution for large U.S. banks."

Journal of Money, Credit and Banking, pp. 94108, 1990.

[15] Rezvanian, R. and Mehdian, S. "An examination of cost structure and production performance of commercial banks in Singapore." Journal of Banking \& Finance, pp. 79-98, 2002.

[16] Wang, C.-J. "An empirical analysis of scale economies and scope economies of U.S. agricultural cooperatives." Taiwan Financial Journal, pp. 181-215, 1996. 